\title{
Importance of multidisciplinary trauma prevention program for youth
}

\section{Importância de programa multiprofissional de prevenção de trauma para jovens}

\author{
Alcir Escocia Dorigatti ${ }^{1}$; Laisa Simakawa Jimenez ${ }^{1}$; Barbara Ribeiro Redondano ${ }^{1}$; Rodrigo Barros de Carvalho, ACBC-SP2; \\ Thiago Rodrigues Araujo Calderan²; Gustavo Pereira Fraga, TCBC-SP²
}

A $B$ S T R A C T

\begin{abstract}
Objective: present the experience of the P.A.R.T.Y. program in Campinas, thereby changing the habits of young people. Methods: The organizers visited the participating schools talking to the students, who are aged between 14-18 years. These students spent an afternoon at the Clinics Hospital of Unicamp, where, for four hours, they attended lectures of the organizers, partners and municipal sectors, and also visited the hospital, talking with trauma victims. Questionnaires were evaluated between2010-2012, being applied before and after the project. Results:2,450 high school students attended the program. The mean age is $16 \pm 0,99$ years and $37.6 \%$ were male. $3.6 \%$ of males already drive while drunk versus $0.8 \%$ of women. Before the project $116(11.3 \%)$ thought that drunk driving wasn't a risk, and only 37 (3.6\%) knew the alcohol effects. After the project, 441 (43\%) began to consider drunk driving a risk and $193(18.8 \%)$ know the alcohol effects when driving. 956 (93.3\%) considered that prevention projects have a huge impact on their formation. Conclusion: It's expected that the attendees will act as multipliers of information, conveying the message of prevention to their entire social circles resulting in reduction in the number of trauma events involving the young, in the long term.
\end{abstract}

Key words: Prevention Accident. Trauma. Alcoholism. Youth.

\section{INTRODUCTION}

Tresers rauma is a disease caused by external causes, which is one of the main causes of morbidity and mortality in Brazil, accounting for $12.5 \%$ of the deaths in 2007, especially among young adults of the male sex, where it represents $83.5 \%{ }^{1}$. Therefore, trauma is the third leading cause of death in the general population (approximately 140,000 deaths per year) and the first cause of death in the population of between 1 and 40 years, predominantly involving homicides and traffic-related accidents, and often associated with the consumption of alcoholic beverages ${ }^{1}$.

The epidemiology of trauma in Brazil differs somewhat from other country members of WHO (the World Health Organization), where $51 \%$ of deaths from external causes are from suicide ${ }^{2}$. In 2007, 38,419 injuries and deaths related to traffic accidents occurred in Brazil, totaling $67 \%$ of the 131,032 deaths from injuries of external causes. In 2007, the homicide rate was 26.8 per 100,000 people and traffic-related mortality was 23.5 per $100,000^{1}$. Brazil's traffic-related mortality rates have been increasing at an alarming rate with regard to motorcycle accidents ${ }^{3,4}$. In the past decade, motorcycle occupant mortality has increased by over 300 percent from 1.5 per 100,000 inhabitants in 2000 to 4.7 per 100,000 in $2008^{4}$.

Campinas is the third most populous city in the state of São Paulo and 14 ${ }^{\text {th }}$ in Brazil, with over 1.1 million inhabitants. In 2008 the city had a traffic-related mortality rate of 20 per 100,000 inhabitants, and motorcycle drivers accounted for $49.3 \%$ of fatal accidents on public roads in Campinas ${ }^{5}$. Carrasco et al. studied 479 cases of deaths from motorcycle crashes in Campinas and observed the following: $90.8 \%$ were male, the mean age was 27.8 (range: $0-73$ ) and blood alcohol was positive in $42.2 \%$ of the victims (mean score: $0.627 \mathrm{~g} / \mathrm{L}$ ), corroborating the fact that alcohol is a significant factor in relation to accidents and is an important risk factor contributing to fatal collisions ${ }^{6}$.

Laws and prevention programs are an excellent long-term solution in reducing traffic-related trauma and general trauma rates ${ }^{7-9}$. An excellent example of such an initiative is Sunnybrook RBC First Office for Injury Prevention, which was established in 1986 within Sunnybrook's Trauma, Emergency and Critical Care department, in Toronto. The office aims to prevent traumatic injuries and injuryrelated mortality across all ages through community education, collaboration and awareness. As well as providing an extensive team of collaborators, various

1. Medical Sciences, University of Campinas, Campinas, SP, Brazil; 2. Division of Trauma Surgery, Faculty of Medical Sciences, University of Campinas, Campinas, SP, Brazil. 
programs and resources are delivered independently, such as the Prevent Alcohol and Risk-Related Trauma in Youth (P.A.R.T.Y.) program ${ }^{8}$.

The P.A.R.T.Y. Program is an initiative in which young people (14 to 18 years) are invited to spend a day in a hospital and take part in specific activities in order to raise awareness of the risks to which they are exposed, and most importantly, how to avoid them. They visit the hospital's departments which serve trauma patients, where they can experience the reality of those who are suffering the consequences of the same risks to which the young people themselves are constantly exposed. This program was initially developed in Canada and has effectively reduced the incidence of traumatic injuries among its participants ${ }^{9}$.

In Brazil, the P.A.R.T.Y. program started in 2008, in the city of Ribeirão Preto. In Campinas, the activities occur in partnership with the Campinas Department of Health, the public high school system's teachers and coordinators, the fire department, military police, SAMU (Servico de Atendimento Móvel de Urgência - Urgent Treatment Mobile Service), medical and nursing students from UNICAMP, as well as physicians and volunteers. During the activities, the professionals raise awareness of the risks to which young people are exposed and their consequences, and by using different viewpoints and approaches, provide opportunities for better life choices.

This study aims to identify the profile of the young people who have participated in the P.A.R.T.Y. program in the city of Campinas, and to present its impact since its implementation in 2010. Other objectives are to raise awareness among academic health-care professionals and the public, focusing on young audiences, and to highlight the importance of multidisciplinary activities in the prevention of alcohol-related traumatic accidents.

\section{METHODS}

The Ethics and Research Committee of the medical science department at the University of Campinas approved this study with protocol 0787.0.146.000-10.

The awareness of participants is achieved through visiting the Clinical Hospital $(\mathrm{HC})$ at the State University of Campinas (Unicamp), where they attend lectures, watch videos identifying risks, choices and consequences related to trauma and pay interactive visits to trauma patients in various hospital sectors, where they have the opportunity to talk with the patients about the causes of their traumas. They also witness sequelae from traumas in simulated and dynamic ways, as well as exchange experiences with volunteers who have suffered severe traumatic injuries and have permanent sequelae, such as paraplegia.

During the activities of the P.A.R.T.Y. Program, participants respond anonymously to a questionnaire about behavior, alcohol consumption and general knowledge about trauma and emergency. This was carried out before starting the project and after program participation, as a way of evaluating its effectiveness.

This study analyzed the responses from these questionnaires from the period 2010-2012, and at the same time highlighted the involvement of a multidisciplinary team during that period. The staff involved during the period consisted of 50 medical students, three nursing undergraduates, a psychologist and four trauma surgeons, plus six educators from EMDEC and 40 from Campinas, the Police participation started in 2011 and five police officers participated in lectures to students, two nurses and two physicians from the pre-hospital emergency unit (SAMU) alternately attended the program. Many patients and families received the students during their own treatment at the Clinical Hospital of Unicamp and were very collaborative, and helpful to the project. One particular patient, who has paraplegia, participated in all of the visits.

\section{RESULTS}

Between 2010 and 2012, 2450 high school students, from 35 public schools from the central and peripheral areas of the city, attended the P.A.R.T.Y. project at the University of Campinas. Each hospital visit included a mean of 70 students.

The complete questionnaire was answered by 1,025 students. The mean age was $16 \pm 0.99$ years, with 72 students (7\%) being over 18, and 385 (37.65\%) being male. Most of the participating students $(956,93.3 \%)$ considered that prevention projects have a huge impact on their education.

From total of the students, 34.4\% had already driven, of whom $54.3 \%$ were male and $22.5 \%$ female. However, $42.5 \%$ of the males and $18.3 \%$ of the females were not over 18 years old. The analysis of safety items (seat belts and helmets) used by students of the program are shown in table 1 . Always used the seat belt $50.5 \%$ of the participants, 3.5\% never used, and $43.4 \%$ always used the helmet when walked in a motorcycle, being 183 $(47.5 \%)$ males and 259 (40.5\%) in the female group. Thereby, we observed that $288(74.8 \%)$ of the young males always or usually used the seat belt when riding in the front seat, versus $515(80.4 \%)$ of the girls. We also observed that only $26 \%$ of the participants from both genders always or usually used the seat belt when riding in the back seat (Table 1).

So it appears that 14 of 385 (3.6\%) of the young male participants had already driven under the influence of alcohol with five of $640(0.8 \%)$ of the young females doing the same. Ten of 19 young people (52.6\%) who had already driven under the influence of alcohol, consume alcohol more than 10 times a month (Table 2). With reference to knowledge about the effects of alcohol on driving, the results, before and after participation in the P.A.R.T.Y. program, are shown in figure 1. 


\section{DISCUSSION}

After years of increase in the death rate related to traffic, there has recently been a registered decrease in this type of death, although not nationwide. Part of this success can be attributed to the measures taken in recent years regarding this issue, such as the reduction in the allowed maximum concentrations of alcohol in the blood

Table 1 - Use of safety items, according to the survey.

\begin{tabular}{|c|c|c|c|c|}
\hline \multirow{2}{*}{$\begin{array}{l}\text { Survey about safety items use } \\
\text { Use of seat belt in front seat (last } 2 \text { months) }\end{array}$} & \multirow[t]{2}{*}{$\begin{array}{c}\text { Male gender } \\
(n=385-37,6 \%)\end{array}$} & \multirow[t]{2}{*}{$\begin{array}{l}\text { Female gender } \\
(n=640-62,4 \%)\end{array}$} & \multicolumn{2}{|c|}{$\begin{array}{c}\text { Total } \\
(n=1025)\end{array}$} \\
\hline & & & & \\
\hline Always & 181 & 337 & 518 & $(50.5 \%)$ \\
\hline Usually & 107 & 178 & 285 & $(27.8 \%)$ \\
\hline Sometimes & 54 & 68 & 122 & $(11.9 \%)$ \\
\hline Rarely & 21 & 39 & 60 & $(5.9 \%)$ \\
\hline Never & 20 & 16 & 36 & $(3.5 \%)$ \\
\hline Never ride in front seat & 2 & 2 & 4 & $(0.4 \%)$ \\
\hline \multicolumn{5}{|c|}{ Use of seat belt in back seat (last 2 months) } \\
\hline Always & 53 & 100 & 153 & $(14.9 \%)$ \\
\hline Usually & 48 & 71 & 119 & $(11.6 \%)$ \\
\hline Sometimes & 70 & 129 & 199 & $(19.4 \%)$ \\
\hline Rarely & 67 & 151 & 218 & $(21.3 \%)$ \\
\hline Never & 143 & 188 & 331 & $(32.3 \%)$ \\
\hline Never ride in back seat & 4 & 1 & 5 & $(0.5 \%)$ \\
\hline Ride a motorcycle (in front or back) & 252 & 350 & 602 & $(58.7 \%)$ \\
\hline \multicolumn{5}{|l|}{ Use of helmets on motorcycles } \\
\hline Always & 183 & 259 & 445 & $(43.4 \%)$ \\
\hline Usually & 26 & 41 & 67 & $(6.5 \%)$ \\
\hline Sometimes & 13 & 17 & 30 & $(2.9 \%)$ \\
\hline Rarely & 9 & 10 & 19 & $(1.9 \%)$ \\
\hline Never & 18 & 23 & 41 & $(4.0 \%)$ \\
\hline Never ride a motorcycle & 133 & 290 & 423 & $(41.3 \%)$ \\
\hline
\end{tabular}

Table 2 - Analysis of alcohol consumption according to the survey.

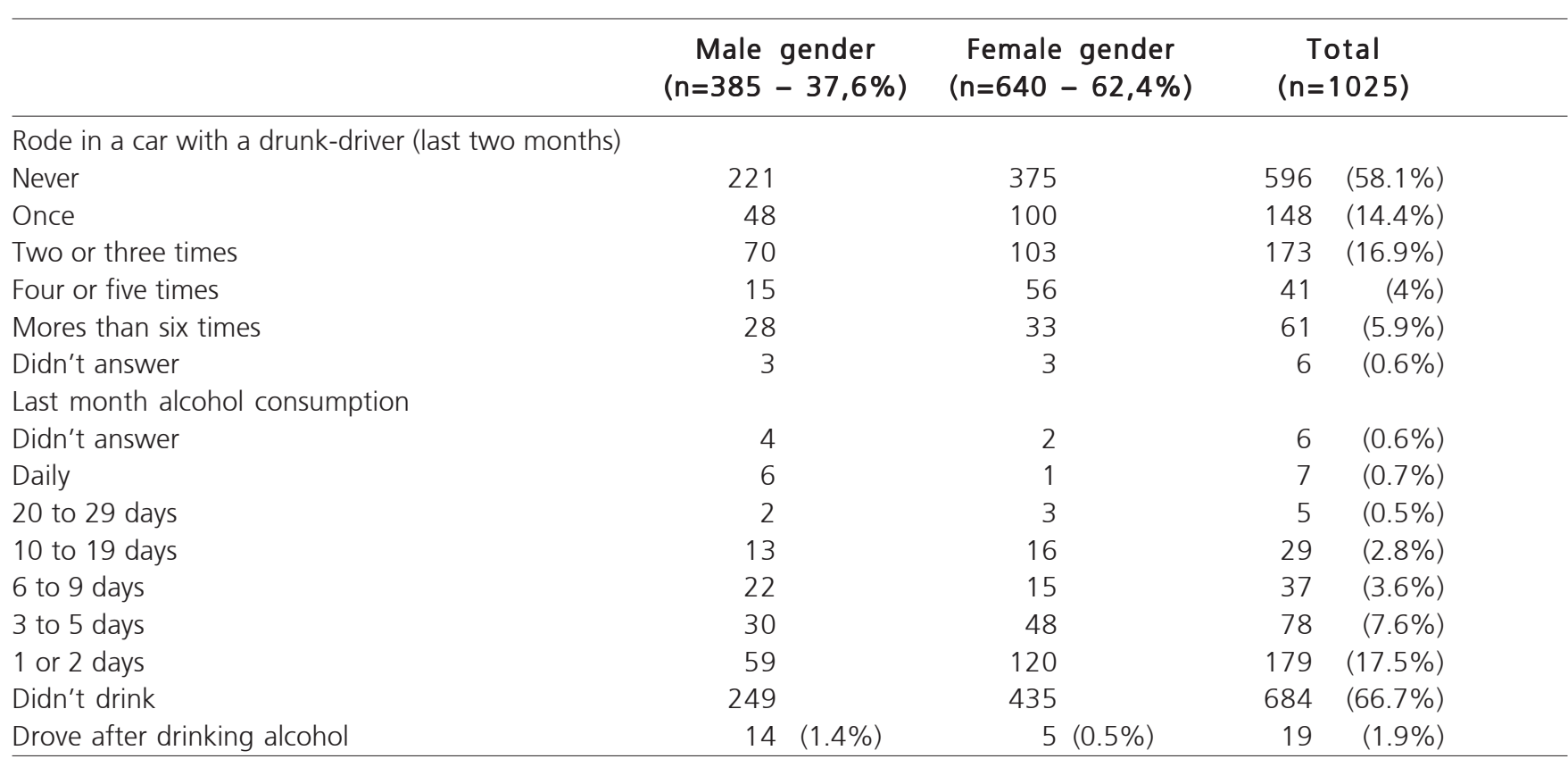




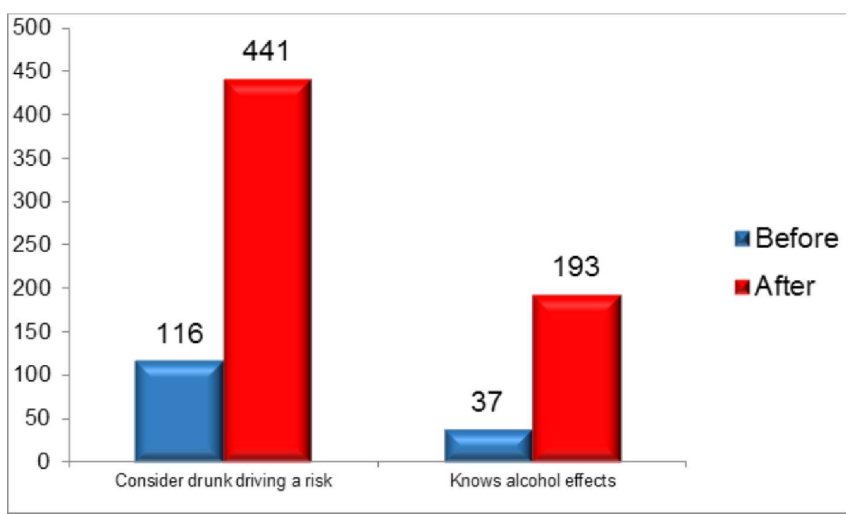

Figure 1 - Knowledge about alcohol use and effects before and after participation in the P.A.R.T.Y. program.

while driving. In 1998, the National Traffic Code specified the legal limit to be $0.6 \mathrm{~g} / \mathrm{L}$, and that use of the seat belt be mandatory. In 2008, law 11705, known as the "Dry Law" ("Lei Seca"), was approved, reducing the legally allowed blood alcohol level while driving to zero ${ }^{1,10}$. Since 1998 there has been a decrease of approximately $14 \%$ in the death rates, but the value has only reached the same value as the Latin American average, and is still above that of other countries. Other studies also suggest that the reduction in death rates is connected to the approval of other traffic laws, such as law 12009, which, since 29/07/ 2009, has stipulated that, to be a professional motorcycle driver, the rider must be at least 21 years old, have possessed a motorcycle license for at least two years, and have passed a specialized motorcycle training course $\mathrm{e}^{10-12}$.

Traffic injuries have a high cost, both personal and social, burdening the public purse with US $\$ 9.9$ billion, or $1.2 \%$ of the Brazilian GDP. Data from the Hospital Information System of 2007 reports 17,265 hospitalizations resulting from traffic-related injuries. According to $\mathrm{WHO}$, we are in a decade of traffic-mortality reduction, nevertheless there are still over 42,000 deaths a year due to traffic accidents in Brazil ${ }^{1,10,13}$. The best way to reduce these numbers is through prevention.

During the specified period, the P.A.R.T.Y program involved about 70 students per hospital visit and about 800 per year in Campinas. This is just a small portion of the young people who are exposed to the daily risks of trauma. Other cities are also considering initiating similar activities through multidisciplinary partnerships and national unification. Although the fruits of these initiatives will only be harvested in the long term, with the proliferation of such projects, traffic-related mortality rates will certainly be reduced in the future.

In Toronto, considering 1,281 students who were randomly matched with control subjects, the P.A.R.T.Y. program effectively reduced the incidence of traffic accidents among its young participants, with the greatest reductions being among females (from $49 \%$ to $44.4 \%$, $\mathrm{p}=0.04$ ) and those youths gaining driver's licenses (from $67.2 \%$ to $60.1 \%, p=0.04)^{9}$. The effectiveness was generally more apparent among females than males. The program did not reduce the incidences of all traumatic injuries but indeed helped its participants to remain free from injury, on average, longer than the control group (898 days vs. 436 days, $p<0.0001)$, and the injury severities to those P.A.R.T.Y. program participants were significantly lower than those of the control group. Banfield et al. demonstrated the effectiveness of this hospital-based program in reducing traumatic injuries. Another study from Australia showed that participation in the P.A.R.T.Y. program was associated with significant reductions in subsequent risks of violence, traffic-related incidents, injuries, and death for juvenile justice offenders, from $26.8 \%$ to $3.6 \%(p=0,001)^{14}$.

A noteworthy aspect of the project is the fact that it was the undergraduate students who organized and delivered most of the information about each day's activities $^{9}$. On one hand, the participants (young people aged between 14 and 18 years) may not have recognized the undergraduate students as being sufficiently trained in order to deliver the information, due to the closeness of age between them, or to the fact that the undergraduate students hadn't yet concluded their studies. On the other hand, the language used by the undergraduate students was closer to that used by the young participants. This appropriateness of language is extremely important to the comprehension of the information delivered, which is often a great difficulty experienced by health care systems. Also, the medical students may have served as good examples.

While observing the students explain about the risks to which all young people, undergraduate students as well as the program participants, are exposed, and the means of preventing these risks from materializing, an identification between the two groups could be seen, by way of introjections on the part of the participants, and by the preventive awareness postures observed among the undergraduate students. These introjections will eventually play a part in the formation of the personalities of those young people.

The participation of the other professionals happened in a dynamic way, with the intention of providing concepts to the young people without overstraining them, through lectures and videos from referenced professionals talking within their respective fields. This multi-professional approach aimed to provide authoritative arguments which supported information previously provided by the medical and nursing students, who discussed the same concepts, but in a more accessible way.

During the second part of the activities, when the youngsters talked with patients in the trauma ward and had a chat with a wheelchair user, who had become a paraplegic at the age of 17 , the intention was to create a moment of reflection through a reality shock. In psychoanalysis, this is known as "the reality principle", which consists of showing the reality of the demands of the world and the consequences of one's own actions ${ }^{15}$. This was carried out by confronting the young people about 
what may happen to them in the future if they continue with behavior which is vulnerable to risk of trauma ${ }^{15}$. The participants observed and imagined themselves as patients hospitalized in the ICU or the trauma ward, and shared the difficulties confronted by the paraplegic volunteer.

Inter-professional education and collaborative practice can play a significant role in mitigating many of the challenges faced by the behavior of young people. Medical and nursing students gain an understanding of the roles and responsibilities of each member of the healthcare team involved in trauma care. These students have a better understanding of the need for communication following the inter-professional project on trauma prevention, having participated in it. The key advantages, that can guide the movement towards inter-professional education and collaborative practice, include: context relevance, integration, multi-level behavior change and collaborative leadership. It is also important to note that hospital users, patients and families are all engaged in the collaborative process.

The continuous development of inter-professional competencies of the students in health-care professions, as part of the learning process, is necessary to prepare them for effective teamwork and team-based care. Learning about topics of prevention is a fantastic opportunity for developing social responsibility, saving lives and creating safer, more effective and more efficient healthcare systems.

There is not a large difference between the genders, as far as traffic safety behavior among youth is concerned, corresponding to our observations. The data infer that behavior is related to age, and not to gender, at least among adolescents, since both male and female participants showed the same behavior concerning the use of seat belts and helmets.

However, as we have seen, there is a possible association between regular consumption of alcohol among young people and the habit of drink-driving, with exaggerated alcohol intake, and the act of driving under the influence of alcohol, both being more frequent among males.

The project was shown to be very efficient as a means of dissemination of knowledge to, and providing experiences for, young people. Before the project, only a few students thought that drink-driving offered no risk, and only $3.6 \%$ of them knew the effects of alcohol on driving. Whereas after the project, $43 \%$ considered drink-driving as a risk and $18.8 \%$ had learned the effects of alcohol on driving.

Despite the results achieved being far from the ideal scenario for young people, the project being regarded solely as a timely initiative, there is no doubt that the results are successful. But it is necessary to expand the number of such projects, and the number of cities where they are implemented, in order to reach a larger population of young people. This is already happening with the creation of P.A.R.T.Y. Brazil under the coordination of the Brazilian Trauma Society (SBAIT), the program already being active in Ribeirão Preto, Campinas, Sorocaba and Vitória ${ }^{16-18}$. It is also necessary to conduct a series of education initiatives to improve the knowledge and safety behavior of the youth.

In conclusion, the emergence of prevention programs such as these enables a behavioral change in the participant population, especially when the programs are performed by a multidisciplinary team, who can discuss the subject from different points of view, each according to their area of expertise. The P.A.R.T.Y. program exists as an option to help young people identify the risks of not using safety equipment in traffic, as well as the negative effects of the combination of drinking and driving.

\section{Acknowledgments}

We thank all fellows of PET-SAÚDE, the medical students of the League of Trauma and HC UNICAMP Campinas, EMDEC employees, volunteers, and everyone in the Trauma Surgery Division of Unicamp, for making it possible to carry out this project.

\title{
R E S U M O
}

\begin{abstract}
Objetivo: identificar o perfil dos jovens que participaram do programa P.A.R.T.Y. na cidade de Campinas e apresentar o impacto deste projeto desde a sua implantação em 2010. Métodos: os organizadores realizam visita às escolas participantes, conversando com os alunos, que tem idade entre 14-18 anos. Esses alunos passam a tarde no Hospital de Clínicas da Unicamp, onde, durante quatro horas participam de palestras ministradas pelos organizadores, parceiros e setores municipais, e também visitam o hospital, conversando com vítimas de trauma. Foram avaliadas as visitas no período de 2010 a 2012, sendo um questionário aplicado antes e logo após o projeto. Resultados: participaram do projeto 2450 estudantes do ensino médio. A média de idade foi $16 \pm 0,99$ anos e 37,6\% eram do sexo masculino. Entre os homens, 3,6\% do total de participantes já dirigiu alcoolizado e 0,8\% no sexo feminino. Antes do projeto 116 (11,3\%) acreditavam que dirigir após beber não era um risco e apenas 37 (3,6\%) sabiam dos efeitos do álcool. Após, 441 (43\%) passaram a considerar um risco e 193 (18,8\%) sabiam os efeitos do álcool. Conclusão: o surgimento de programas de prevenção possibilita a mudança de comportamento na população participante, principalmente realizada por equipe multidisciplinar, que apresenta o assunto estudado sobre diferentes pontos de vista, de acordo com sua área de atuação.
\end{abstract}

Descritores: Prevenção de Acidentes. Trauma. Alcoolismo. Jovens. 


\section{REFERENCES}

1. Reichenheim ME, de Souza ER, Moraes $C L$, de Mello Jorge $M H$, da Silva CM, de Souza Minayo MC. Violence and injuries in Brazil: the effect, progress made, and challenges ahead. Lancet. 2011;377(9781):1962-7.

2. Krug EG, Dahlberg LL, Mercy JA, Zwi AB, Lozano R. World report on violence and health. Geneva: World Health Organization, 2002.

3. Deaths from motor vehicle traffic accidents in selected countries of the Americas, 1985-2001. Epidemiol Bull. 2004,25(1):2-5.

4. Chandran A, Sousa TR, Guo Y, Bishai D, Pechansky F; Vida No Transito Evaluation Team. Road traffic deaths in Brazil: rising trends in pedestrian and motorcycle occupant deaths. Traffic Inj Prev. 2012;13Suppl 1:11-6.

5. Marín-León L, Belon AP, Barros MBA, Almeida SDM, Restitutti MC. Tendências dos acidentes de trânsito em Campinas, São Paulo, Brasil: importância crescente dos motociclistas. Cad Saúde Pública. 2012;28(1):39-51.

6. Carrasco CE, Godinho M, Berti de Azevedo Barros M, Rizoli S Fraga GP.Fatal motorcycle crashes: a serious public health problem in Brazil. World J Emerg Surg. 2012;7Suppl 1:S5.

7. Jayaraj R, Thomas M, Kavanagh D, d'Abbs P, Mayo L, Thomson V, et al. Studyprotocol: Screening and Treatment of AlcoholRelatedTrauma (START) - a randomized controlled trial. BMC Health Serv Res. 2012;12:371.

8. Prevent Alcohol and Risk-Related Trauma in Youth (P.A.R.T.Y.) Program. Acesso em: 30 mai 2014. Disponível em: http:// www.partyprogram.com

9. Banfield JM, Gomez M, Kiss A, Redelmeier DA, Brenneman F. Effectiveness of the P.A.R.T.Y. (Prevent Alcohol and Risk-related Trauma in Youth) program in preventing traumatic injuries: a 10year analysis. J Trauma. 2011;70(3):732-5.

10. Bacchieri G, Barros AJD. Trafficaccidents in Brazil from 1998 to 2010: manychanges and feweffects. Rev SaúdePública. 2011:45(5):949-63.
11. Cheng AS, Ng TC. Risky driving and the perception of motorcycle accident causes among Chinese motorcyclists in Hong Kong. Traffic Inj Prev.2012;13(5):485-92

12. Híjar M, Pérez-Núñez R, Inclán-Valadez C, Silveira-Rodrigues EM.Road safety legislation in the Americas. Rev Panam Salud Publica. 2012;32(1):70-6.

13. Peden M, Scurfield R, Sleet D, Mohan D, Hyder AA, Jarawan E, et al. World report on road traffic injuries prevention. Geneva: World Health Organization, 2004.

14. Ho KM, Litton E, Geelhoed E, Gope M, Burrell M, Coribel J, et al. Effect of an injury awareness education program on risk-taking behaviors and injuries in juvenilejustice offenders: a retrospective cohort study. PLoS One. 2012;7(2):e31776.

15. Richter ED, Berman T. Environmental and occupational medicine and injury prevention: education and impact, classroom and community. Public Health Rev. 2002;30(1-4):277-92.

16. Sociedade Brasileira de Atendimento Integrado ao Traumatizado (SBAIT). Lançado o P.A.R.T.Y. Brasil. TRAUMA BoleTEAM, ed. 2, $2^{\circ}$ trim. 2013, p.6-7. [Acesso em 30mai2014]. Disponível em http:// issuu.com/sbait/docs/informativo trauma jul-13

17. P.A.R.T.Y. Brasil. Sociedade Brasileira de Atendimento Integrado ao Traumatizado (SBAIT). [Acesso em 30mai2014]. Disponível em http://www.sbait.org.br/partybrasil/

18. Dorigatti AE, Matos MP, Calderan TRA, Carvalho RB, Scarpelini AHP, Banfield JM, et al. The rising of a national program on injury prevention on youth in Brazil. Eur J Trauma Emerg Surg. 2014:40(Suppl1):58.

Received on 01/11/2013

Accepted for publication 03/01/2014

Updated 05/2014

Conflict of interest: none.

Source of funding: Programa de Educação pelo Trabalho para a Saúde (PET-Saúde), Ministério da Saúde, Brazil.

\section{Corresponding author:}

Gustavo Pereira Fraga

E-mail: fragagp2008@gmail.com 